\title{
A Posture of Protest? The Search for Christian Identity in A Post-Secular Society: Between Secularised Eschatology and A Sacralisation of History
}

\author{
Mariëtta D.C. van der Tol ${ }^{1}$ and Matthew Rowley ${ }^{2}$
}

\begin{abstract}
This article theorises ideations of "the people" in a comparative reflection on Latin-Christian theologies and typologies of time and secularised appropriations thereof in right-wing as well as far-right movements in Europe and the United States of America. Understanding the world in grand narratives of "good" and "evil" emerges from Christian eschatological hope: the hope of the restoration and renewal of the cosmos and the final defeat of evil prophesised in association with the return of Christ. However, this language of good and evil becomes detached from the wider corpus of Christian belief and theology. In its secular expression, it may attach the good to an abstract and normative account of "the people", who are defined in contrast to a range of others, both internal and external to the nation. Secular iterations might further echo the stratification of present, past and future through a sacralisation of the past and a dramatization of the future. The context of contemporary right-wing and far-right movements poses a series of questions about the relationship between belief and belonging, the acceptability of the secularization of Christian traditions and theologies, and the extent to which Christian communities can legitimately associate with right-wing movements.
\end{abstract}

Keywords: Christian identity; right-wing populism; time; people; othering; sacralisation

\section{Introduction}

Feelings of "loss" often animate supporters of right-wing and far-right movements in Latin-Christian contexts: a sense that a familiar environment has changed to the extent that it is difficult to feel at home in it. This might reflect cultural changes brought about by secularization, individualization, and immigration (Eatwell \& Goodwin, 2018; Whitehead \& Perry, 2020). Or it might have to do with declining economic prospects. Right-wing movements take this sense of loss seriously and have developed their own language and vocabulary to give voice to feelings of discomfort, discontent, and anxiety. They prominently speak of "the people", who are set apart from the wider population, whose past is idealized and whose future depends on the curbing of "evil forces" in contemporary society (Arato, 2013). This article theorises ideations of "the people" in relation to the interplay between perceptions of the past, the present, and the future, as well as to the perspective of different meanings that are ascribed to time in the Latin-Christian tradition. Scholars like Reinhart Koselleck and Johannes Fabian have spoken about time in terms of physical time or natural time, which might be ordered in mundane time, like ages or decades, or weeks (Koselleck, 1979; Fabian, 1983). They also developed ideas about typological time: the ascription of meaning to time through images, narratives, and symbols. The coexistence of diverging ascriptions of meaning to time can give rise to othering:

\footnotetext{
${ }^{1}$ Dr Mariëtta D.C. van der Tol, Alfred Landecker Postdoctoral Research Fellow, Blavatnik School of Government, Oxford Non-stipendiary Junior Research Fellow, New College, Oxford, United Kingdom. E-mail: marietta.vandertol@bsg.ox.ac.uk.

2 Dr Matthew Rowley, Honorary Visiting Fellow, Department of History, Politics and International Relations University of Leicester, Leicester, LE1 7RH, UK. E-mail: mpr22@le.ac.uk. https://orcid.org/0000-0003-2762-0667
} 
not just relative to outsiders, foreigners or migrants, but othering within an existing political community, including, but not limited to, "elites" (Mudde, 2017).

This article explores the relationship between Christian theologies of time and secular expressions thereof in right-wing and far-right movements in Europe and North America. Understanding the world in grand narratives of "good" and "evil" emerges from Christian eschatological hope: the hope of the restoration and renewal of the cosmos and the final defeat of evil prophesised in association with the return of Christ (Hayes, 1987; Moltmann, 2004). However, this language of good and evil can become detached from the wider corpus of Christian belief and theology. In one of its secular expressions, it attaches the good to an abstract and normative account of "the people", who are defined in contrast to a range of others, both internal and external to the nation. In order to sustain this narrative, right-wing movements emphasise the typological dimension of the people: through a sacralisation of the past and a dramatization of the future. Only through curbing evil in contemporary society, can the integrity of "the people" be saved. What is important is that this secular expression of eschatological hope brings about a separation of the people and "the people". It is through a conjunction of this normative account of "the people" and its emphasis on popular sovereignty that right-wing movements are able to sustain a posture of protest. This posture of protest holds together a normative claim to dominance (in typological time) with a language of being threatened (in physical time).

The search for Christian identity is not new to post-secular societies, nor is it the exclusive business of churches. From its inception, Christianity has navigated various typologies of time in order to make sense of its position and role in society and these processes have always been influenced by social processes and political pressures. The context of contemporary right-wing movements poses a series of questions about belief and belonging, the acceptability of the secularization of Christian traditions and theologies, and the extent to which Christian communities can legitimately associate with right-wing movements. Rather than answering such questions, this article seeks to offer a theoretical framework for understanding part of the constitutive relationship between Christian theology and secular-Christian ideations of "the people" in right-wing and far-right contexts. Sections two and three develop a theoretical framework around theologies and philosophical typologies of time, eschatological hope, and the way these reinforce temporal otherings of other members of society. Sections 4 and 5 illustrate how a secularised Christian typology of time reinforces the fragmentation of "the people" and the people. As these latter sections draw on a range of invocations of "the people" in right-wing and far-right movements in North America and Europe, the theoretical framework serves as a point of common reference. Unravelling these theological and philosophical dimensions to ideations of "the people" might provide greater insight into the study of modalities of "the people" in political science. As we explore these complex relationships, it is important to recognise that this is not simply about a "hijacking" of Christianity (Marzouki et al., 2016) - the story of Christianity and right-wing movements is more complex and nuanced than that. Without cheaply denouncing right-wing movements, this issue seeks to critically understand these complexities and nuances and raises questions about how they might be further explored.

\section{Theologies and typologies of time, and the other}

Christian theology has historically been significantly invested in time, ranging from a fascination with the world's beginnings to the anticipation of the end times and the return of Christ. Biblical stories enable a layering of interpretative meaning to the Christian experience, often based on the discernment of certain themes: for example, cycles of falling into sin, prophetic callings to repentance, 
and conversion; cycles of tribulation, exile and redemption; and the centrality of mediator figures like Moses, King David, and Christ (Strommen, 2021; Boer, 2009; Otieno, et al., 2016). These stories allow time to be understood figuratively and typologically, as Reinhart Koselleck explicated in Future's Past. What is significant, is that these typologies of time coexist with physical or natural time as it were: the passing of time with events that are irreversible or shaping of historical processes. This physical or natural time may be broken up into periods or ages. This is perhaps best represented by a calendar or a clock. Thus, physical, mundane, and typological time may coexist, but as Koselleck observes, they are not always congruent. In political theory, this possibility of incongruence is understood as the 'contemporaneity of the noncontemporaneous' (Koselleck, 1979: 95).

This possibility of coexisting yet incongruent perspectives on time plays a significant role in othering. Building on Koselleck, the anthropologist Johannes Fabian argued that "the other" could be viewed as existing in another time (Fabian, 1983). This could refer to the idea that "primitive" people would need to level up to the European experience; that Jews would be like "children" and Blacks would be less capable of rational decision-making (Fabian, 1983; Beckmann, 2002; Ilany, 2018; Jennings, 2010; Carter, 2008). A more recent example would be the idea that Islam needs a "reformation" or an "enlightenment" (Abaza, 2007). The common phrase of being on the "right side of history" is also relevant as an assured hope that time itself will vindicate one's cause. The key insight is that temporal othering ascribes a sense of superiority to the self as well as construing the other in a way that places them in a different reality. Taking aim at the orientalization of the other and the justification of imperial activity through the temporal (and spatial) distancing of the other, Fabian argued that layers of temporal othering are always implied in anthropological research. He also argued that temporal incongruence, or 'the denial of coevalness', as he calls it, hinders genuine interaction, and as it were, seems to give permission to not actually engage with the other (Fabian, 1983; Jennings, 2010).

Whilst this theorization of othering refers to a context in which spatial othering is often implied, the same logic is useful in understanding othering within a country or within a nation, or "people". This could of course apply to Muslims, who are often othered as coming from another place as well as from a lesser advanced time (Barbero, 2012). Whereas this orientalization is perhaps a more obvious form of othering, it can also happen on an ideological level within communities. In the United States of America, for example, opponents of the Right frequently describe conservatives as coming from a different era and from another space, e.g. the uneducated Bible Belt (Hart, 2020: 151; Rowley, 2021: 22). This type of rhetoric facilitates the objectification of the other, seemingly giving permission to not fully engage them as equals. But something similar can happen in conservative Christian communities, who might employ narratives of exile for example, or a call to repentance and the anticipation of the coming of Christ, in their understanding of the place of the church in a society that seems increasingly secular, plural, and individualist. This is best exemplified in the popularity of counterculturalist ideologies among conservative Christian communities. Such typological layers may gradually become dominant to the extent that Christian imaginations of time take precedence over the "shared" physical as well as other typological layers of time.

Christian self-imaginations emerge from the complex and multi-layered collection of texts that we know as the Bible. Both Koselleck and Fabian argue that typological time is largely derived from biblical interpretation and, as a result, carries an inherent claim to normativity (Koselleck, 1979; Fabian, 1983). However, typological temporalities might refer to differing themes even within the Bible. For example, the narrative of creation might confer a meaning of becoming (genèse) to physical or natural time. The figure of Christ gives this becoming a more complex meaning, especially as "the 
church" develops differently from "the world", and believes in the prospect of eternal life. On a political level, Christian imaginations may be understood to take on a covenantal status akin to that between God and biblical Israel, a covenant that might be variously applied to the Church, churches or even nations (Gorski, 2017). At once, Christian imaginations might employ the narrative of exile, as a disruption to redemptive consciousness, or as a punishment for the sins of the community. Furthermore (and certainly not exhaustively), Christian imaginations of time have been deeply influenced by the anticipation of the consummation of creation in the second coming of Christ. The more a society is secular or less confessionally Christian, the more society may be experienced as incongruent with these narratives. As a result, these narratives might play into dynamics of othering and self-othering: an othering of society, or "the world" vis-à-vis Christianity, as well as a selfothering, for example in emphasising how churches are different from society or "the world". Whilst not identical, these processes interrelate in Christian imaginations.

The decline of church attendance or membership, as well as the transformation of Christianity's political significance, may contribute to this othering of society. This could take the shape of discontent over political decisions on ethical issues, including same-sex marriage, abortion and euthanasia; but also conflicts over the way gender and sexuality are taught in schools or the obligation to use certain pronouns. Especially as many of these issues may be understood as contradictory to biblical teachings (though Christians too can hold different opinions on these matters), their political prevalence might affirm the "otherness" of wider society. This othering might be amplified by church-world and other dualities that emerge from the New Testament, which can provoke a sense of displacement among conservative Christian communities. The sense of displacement signals a growing temporal incongruence, namely between those who understand time primarily in relation to biblical narratives and those who do not or do so differently. This incongruence has the capacity to evoke sentiments of "being a minority", or a "faithful remnant" of a faith community that may historically have determined much of the local Christian culture. At the same time, eschatological anticipation might colour how such a Christian community sees the world: for some, this means to actively seek its re-Christianization, whereas for others the immediate interest is to withdraw from society in order to retain a measure of godliness in contrast with society, e.g. the Benedict Option, counterculturalism (Dreher, 2017; Hauerwas \& Willimon, 1989; Smith, 2017).

Whereas biblical typologies of time are not inherently illegitimate, the relative dominance of certain typological narratives of time (and space) can become problematic where this Christianity objectifies "the world" as comprehensively other. This objectification of "the world" implies a permission to not fully engage with it, but rather to "witness" to it, against it even, "calling for repentance". In some cases, it might even carry an obligation to dissociate from it as a modality of self-othering: for example by withdrawing into local bastions of faith, seeking exemptions from certain legal obligations, or invoking the freedom of conscience (McIvor, 2021). The latter is perhaps the most serious form of self-othering, as an expression of the forum internum which is different from and godlier than "others". Whilst appeals to the freedom of conscience can be entirely legitimate, these appeals also risk being instrumentalized in processes of othering and self-othering. Ultimately, the giving of meaning to physical time on the basis of certain dominant biblical narratives may feed into the frustration of political hopes, as well as enable and justify political polarization.

\section{Eschatological hope and political frustration}

Koselleck's Future's Past discusses how people understand the past and the present, and argues that incongruences in those understandings catalyse conflict in the present (Koselleck, 1979). He is aware 
of how imaginations of the future can shape the present too. His scholarship on time is influenced by a deep suspicion over utopian ideologies and the projection of specific expectations onto the future. The future, however, remains significant as different groups entertain diverging visions of where a society is and ought to be headed. This might take the shape of the utopian, but not necessarily so. In the Christian imagination, the future is broadly imagined through the lens of the "end times" and the always imminent "return of Christ", culminating in the divine restoration and renewal of the cosmos. This shapes an eschatological typology of time, which is informed by biblical stories, symbols, and allegories drawn from prophetic writings, the Gospels, and the Apostolic letters (Suchocki, 2005; Westhelle, 2012). An eschatological typology of time might render certain events and processes obstructions to the moral future of "the people". Whilst obstructions might fit the categories of acceleration and suspension that are found in the Book of Revelation, prolonged frustration of hope can be discouraging: what if the future always remains the "not yet"? What if this future takes the appearance of a utopia?

Of course, specific beliefs about the "end times" differ greatly between and within conservative Christian communities and this impacts how new historical events and processes are interpreted. Some foresee declension and apostasy in the near future, and they may be tempted to withdraw and protect their godliness, or perhaps they define themselves by enmity towards this otherness. Some might believe God works through his Church to restore individuals and societies in the near future, and they may pursue the "Kingdom" through politics or civil engagement. Either posture could legitimise domination of or disregard towards those who are deemed opponents to God's plans. A vital characteristic of many differing eschatological typologies of time is the drama of good and evil, and the anticipation that a triumph over evil will eventually follow. In this sense, the "end times" are always connected or contemporaneous with physical and mundane time. Or to put it differently: events and processes that occur in physical and mundane time are inextricably connected with the end times. As a result, those who think differently are othered in relation to typological, mundane and eventually physical time too: the divergence in understanding of time creates "different realities", in which "others" become not just opponents of certain Christian ideals, but "opponents of God". Whilst this of course does not result from eschatological theologies as such, an excessive typological othering can drive Christian imaginations into casting reality into the light of a thesis-antithesis duality.

The duality in good and evil of the thesis-antithesis transcends everyday complexities of good and evil. For example, the "godly" may still be embattled by all sorts of sins, and the "ungodly" may show great virtue. Growth in discipleship, with all its ups and downs, is located in "the good", whilst virtue in the "ungodly" may not elevate them from "evil". In that sense, the understanding of the present is not only shaped by, but also determined by, the understanding of the future. Two stories might help clarify this ambivalence: the story of the wheat and the tares (Matthew 13) and the story of the separation of the sheep and the goats (Matthew 25). These stories have played a significant role in historical discourses on toleration and the coexistence of the church with its others (van der Tol, 2020: 4; Byrd, 2002: 87-127, 231-233; Rowley, 2017: 69; Walsham, 2006: 239). In the first story, weeds are allowed to grow alongside the wheat, and it is for the protection of the wheat that the weeds are not destroyed. Hence, good and evil coexist in the world for the benefit of "the good". The separation of the sheep and the goats is told in the context of the return of Christ, when sheep (the good ones) and the goats (the evil ones) are separated. In the biblical context, sheep and goats are actually very difficult to tell apart. This could help us understand ambivalences and complexities in the everyday experiences of good and evil. 
As a result, the cause of "the good" may be defended by a variety of agents, irrespective of how they understand themselves in relation to biblical as well as everyday notions of good and evil. The Old Testament narrative of King Cyrus is a helpful example: the king of Babel (picture of evil) orders the temple in Jerusalem to be rebuilt and allows Jews to return to their land, thus restoring the vocation of the people of God. During the Trump presidency, this story was regularly referenced to explain the relationship between evangelicals and the not-so-godly President (Rowley, 2019). Supporters said that what mattered was that Trump's actions contributed to "the good". Or perhaps they used a different definition of good and evil from Trump's opponents. In order to make this logic work, Christian imaginations need to separate the typology of good and evil from everyday experiences of good and evil. In the language of time, this is a differentiation of typological and physical time. This differentiation is significant, because Christian imaginations of time tend to stress a normative coherence of typological and physical times, and the trauma of declining Christendom lies precisely in the deconstruction of these coherences (Westhelle, 2012). This logic is crucial to understanding the alliances that some conservative Christians are willing to form with right-wing movements. Leaving aside how the political interests between these groups might intersect and overlap, the key is that these movements can claim to be "defenders of the faith", which indeed they do.

This possibility is quite separate from the question of who are the bearers of Christian identity, or who should be the bearers of Christian identity. In the context of right-wing populism, this question is conceptually mediated through the differentiation of belief and belonging. Right-wing populist movements may actively contribute to a further secularization of Christian identity (Elcott et al., 2021: 27). This is because belonging voided of belief legitimises a culturalized Christianity that can be politically instrumentalised against cultural others. Note the concessions that are done to the integrity of eschatological imaginations: 1) there is an implicit acceptance of the incoherence of typological and physical time; 2) this incoherence is instrumentalised to seek alliances with those who do not identify with Christian beliefs; 3) these alliances implicitly accept the possibility of a culturalized Christianity that is void of beliefs. The result of which is that, 4) Christianity is instrumentalised in conflicts between groups of people, for example right-wing movements versus Muslim migrants, either of whom might be considered "others" in the eschatological typology of time. Whereas some might speak of a hijacking of Christianity on behalf of right-wing movements, the above steps cannot be the result of hijacking from some "outside" group; this can only occur as a result of changes within Christian communities themselves, insofar as they aid and abet the instrumentalization of their identity for political purposes (e.g. Van de Breevaart, 2020).

At this point, we are well beyond a duality of the sacred and the secular that Fabian initially employed. The sacred is not just about Christianity or even religiosity more broadly, as the sacred can be coopted by culturalized renditions of Christianity. In fact, the sacralisation of time as a social phenomenon may not need Christian belief and theology at all, even as it might remain culturally dense and steeped in Christian imaginations. It is perhaps more appropriate to speak of sacralisations and secularisations of time, which may occur at once. For example, when right-wing movements coopt Christian narratives and choose to instrumentalise biblical typologies to define its "others", this co-optation not only contributes to secularisation - their implicit and culturalized sacralisation of time $i s$ the secularization thereof. And it is the conflation of culturalized sacralisations of time with the eschatological typology of time in the Christian imagination that facilitates the ideological coexistence of the Christian Right and right-wing populist movements. The question is, given the concessions given to the eschatological imaginations, what integrity is left to Christian imaginations and narratives about the eschatology, and about eschatological hope? 
Eschatological typologies of time - in their Christian and co-opted expressions - play a significant role in polarization. Although this polarization appears to be strongest in the USA, European countries have witnessed it too (Carothers, 2019; Vachudova, 2019). The previous section spoke of placing the other in a different time, or denying "coevalness" as Fabian put it. The use of eschatological typologies of time is perhaps a prime example of placing people in a different time: those journeying to the restoration and renewal of the cosmos and those who are not. It is not unsurprising that deep political conflict provokes this sort of temporal othering. The layering of such conflicts with the typologies of time that divide the world into good and evil can create distance in space and in time between individuals and groups, and ultimately, accepts the fragmentation of society in the present. Such conflicts might be given a more than temporal character, and in their extreme form may invoke the connotation of a spiritual war, or what Mark Juergensmeyer calls a "cosmic war" (Juergensmeyer, 2001: 149-50). The consequence of the association of the other with evil is that they have no permanent and legitimate claim to participation in a shared future. This future might pertain to the restoration and renewal of the cosmos - or more concretely and practically, it has the power to undermine the shared enterprise of a political community that constantly moves between the present and the future.

\section{The fragmentation of the people in right-wing and far-right ideations of "the people"}

One of the ways in which the temporal othering manifests itself is in the different account of "the people" in contemporary right-wing populism as well as ideations of "the people" on the far-right. This normative connotation of "the people" lies beyond the othering of foreigners, immigrants or Muslims, and in some contexts, Jews, relative to ethnic or cultural renditions of the nation. In American Babylon, Philip Gorski writes that 'Right-wing populism is a political ideology that pits the common people against a corrupt elite that has allied itself with an undeserving other, and the leader as a man of the people and the scourge of the elites who will defend the people and expel the invading other' (Gorski, 2020: 112). Similarly, Jan-Werner Müller describes two hallmarks of populism as antielitism and antipluralism (2016: 2). Some scholars refer to these features as the vertical and horizontal dimensions of populism. Vertically, populists reject the elevated status of elites and elite forms of knowledge. Horizontally, they position their politics in opposition to outsiders (Ozzano \& Bolzonar, 2020). Populism can take different shapes depending on factors like the history, politics and religion in a region, as well as the current obstacles that are understood as threats to "the people". This article draws out the specific idea that one defends "the people", an ideation which appears in different modalities of right-wing populist and far-right movements. Though the rhetoric of "the people" versus the elites is powerful, right-wing movements employ a range of contrasts, which can allude to religion, race, class, gender, culture, values, political orientation, geographical location or any combination thereof (van der Tol, 2020; van der Tol, 2021; Stögner, 2020).

What these contrasts share is that invocations of "the people" are primarily negative and can rely on a multiplicity of contrasts and otherings that may not necessarily cohere. Right-wing politicians can employ different sets of contrasts depending on the context or the object of political disagreement. And it also enables individuals and groups who may hold incompatible views to identify with "the people" on an abstract level. The differentiation of "the people" from the people represents more than politically convenient flexibility. Whilst many political movements refer and appeal to the people, most of them would recognise that they represent a specific part of the people (Müller 2016:2-3, 37). In party-systems, this is made explicit through elections and the fact that people either vote for a 
party, or technically, even a specific party representative. Hence, the differentiation of "the people" from the people is about something else: couched in the language of "the right kind of people" and "the wrong kind of people", this account of "the people" amounts to a moral claim (Chaplin, 2021). The association of these others with evil, usually through a rhetoric of fear and doom, is significant. It stems from an eschatological typology of time which divides the world into good and evil, and which is employed in a predominantly secular manner. In this way, populist renditions of "the people" are somewhat reminiscent of the question of what the "true church" is in Augustine's two kingdoms. However, this logic is detached from Christian theology and tradition as such, and is employed secularly for specific political ends.

Most notably, the language of "the people" can be employed to contest political legitimacy. It matters who the people are in any democracy. In its normative sense, it is the people who confer legitimacy on the state and its institutions. It is no accident that right-wing movements employ "the people" as a proxy for popular sovereignty, cultural religion, or perhaps the "natural" nation (Elcott et al., 2021: 27, 32-36; Lee, 2019). It gives populists a powerful rhetoric in challenging democratically elected governments. In principle, it makes little difference if populists hold a democratically elected majority, or if they exist as Parliamentary fringe groups: they can always claim to represent "the people", come what may. For example, it allows for the coexistence of the de facto recognition of the Biden administration with the claim that this administration would in another sense be illegitimate or unrepresentative. Defining a portion of the population as "the people" can have pernicious effects. It might support exclusionary policies, ranging from impaired access to citizenship and political participation to inequities in the distribution of resources. Where right-wing movements hold political power, this can have a devastating effect on those who are deemed outsiders, including but not limited to minorities and vulnerable people.

Discourses about who are not counted among "the people" can easily overflow in discrimination and violence. The threat of violence from the extreme right is real and has been demonstrated by individual acts of domestic terrorism as well as the rallying of fringe groups around violent protests, as Rowley's article in this special collection details. Perhaps the clearest example was the storming of the U.S. Capitol on 6 January 2021. A wide range of groups joined what seemingly began as a protest, but soon erupted into rage and destruction, because of an alleged betrayal of "the people". News outlets showed a chilling mixture of Christian symbols, antisemitic imaginary, symbols of extreme right movements, and physical violence (Green, 2021). Protesters argued that the disruption of constitutional norms was justified because votes came from the wrong sort of people (illegal immigrants' or computer hackers) or were cast in the wrong way (mass absentee ballots or votes received after the deadline). A wide range of political interests converged with different religious communities, and what united them was a powerful and carefully curated narrative of "the people". This was dramatically demonstrated when some of the insurrectionists uttered a prayer on the Senate floor, dubbed a "sacred space". Jack Angeli briefly interrupted his prayer as he forgot to take off his hat - and started again. He then prayed "...this is our nation, not theirs", after a reference to "all the tyrants, the communists and the globalists". In this sense, he might not have aimed his anger at the institution or the space, but at "the enemies" of "the people" who in his mind dominated this sacred space.

3 'A Reporter's Footage from Inside the Capitol Siege', The New Yorker. Online: https://www.youtube.com/watch?v=270F8s5 TEKY\&feature=emb_title (Retrieved 18 January 2021). 
Still more worrying than this eruption of violence was the absence of a strong condemnation by many in the Republican party. Even in disrupting the constitutional and democratic process of certifying elections, many politicians asserted that the insurrectionists represented the people and came to the rescue of its institutions. This gives a certain legitimation to the idea that far-right groups can protect "the people" with violent means. Such far-right groups exist in Europe as well, where they may engage in violence aimed at minorities and refugees - thus assuming the role of defenders of "the people". Dutch security expert Sterkenburg documents a conversation with two young men who identify with the extreme right (Sterkenburg, 2021). We translate part of a conversation between the author and an interviewee called Damian:

Damian: 'I wouldn't hurt innocent people. But I wouldn’t hesitate

pulling the trigger to a bunch of Zionists in Parliament or in Brussels.'

Sterkenburg: 'But you don't make plans?'

Damian: 'Absolutely not. I could not murder people.'

Sterkenburg: 'But you would pull the trigger, you just said.'

Damian: 'I don't call that people' (...)

Some states actively prosecute members of radical- and extreme-right groups, like in Germany and Norway, where extreme-right violence can be prosecuted under the category of terrorism (Strommen \& Schmiedel, 2020). At the same time, some governments refrain from cracking down on such groups. For example, some far-right groups in Hungary patrolled the borders during the most recent migrant crisis, or have been terrorising traveller communities in rural areas (Póczik \& Sárik, 2019). Not only are far-right groups enabled and abetted in their assumed role of defenders of "the people", but the intersection of the language regarding "the people" also plays a significant role in mainstreaming the far-right (Bozóki, 2017; Cammaerts, 2018).

It would, however, be a mistake to blame the right-wing for the mainstreaming of the far-right writ large, nor are differentiations of "the people" from the people limited to politics on the right. For the purposes of this article, we argue one must be attuned to the repertoire and flexibility of othering and their typological significance to understand the intersections between conservative Christianity, rightwing movements, and the far-right. The complexity of this repertoire is confusing to many and difficult to fully discern. Anecdotally, many people have expressed the feeling of existing on a "different planet" when compared to others they talk with. The particular lens of the typological temporal othering might help to explain why appeals to "the people" never seem to really speak to the people as a whole. Or perhaps how one can be culturally significant yet experience their situation as marginalised or minoritized. Or perhaps, how it is conceivable that someone might embrace equality in physical and mundane time, and yet maintain a sense of superiority in their typological understanding of that same time. Or lastly, how one might feel strongly about migrants in general, but not about the few who have integrated locally. Rather than dismissing such contradictions as irrational or describing them in other pejorative terms, it is important to understand the repertoire of othering and its typological significance. 
110 A Posture of Protest?

\section{Sacralisations of people and history}

The association of "the good" with "the people" amounts to its sacralisation. This sacralisation builds on eschatological typologies of time, which understand the unfolding of history as an unveiling of good and evil. The previous sections considered this typology of time in relation to the present and the future. This section discusses its relationship with the past. Stories of becoming shape the contours of belonging (Soper \& Fetzer, 2018: 225-30), but that in itself does not amount to a sacralisation of history. What is needed for the sacralisation of history, is the semantic connection of these stories of becoming and belonging with a grand narrative of good and evil. In this way, past, present and future are reconnected through a complex layering of meaning and time. It is through this intimacy with a sacralised past that eschatology is performed in the present. Right-wing populist movements have chosen very different strategies. Those who operate in culturally Christian environments may choose to idealise a golden age of Christendom in Europe, or in the case of the United States, the religious piety of the Pilgrims (Rowley, 2021). However, other figures, like the elitist Dutch right-wing party leader, Thierry Baudet, refer to the Enlightenment as well as Ancient Greco-Roman culture ("the owl of Minerva"). These stories produce a sense of awe about the nation. What is significant, is that though the sacralisation of history often courts religion, it is not normatively dependent on it: Christianity is not the key, sacralisation is.

In the United States, Christian Nationalism is often put at the service of this sacralisation. As Whitehead and Perry put it: "Christian nationalism is a cultural framework that blurs distinctions between Christian identity and American identity" (Whitehead \& Perry, 2020: 15). This Christian nationalism is not necessarily dependent on Christian thought and belief. Donald Trump drew much of his support from a secularised form of (White) Christian nationalism (Davis \& Perry, 2020). The stories that are attached to White Christian Nationalism involve the perception of the decline of a certain morality, a certain way of life, and order. Because these stories are often "half-conscious" (Gorski, 2020: 109), it is possible to read specific religious ideas into them even as the religious elements can influence ideas of belonging in ways that go unnoticed. In the case of America, a prime example would be the political semantics surrounding talk of the Founding Fathers. The sense of moral decline, the loss of a way of life, and of a certain order, are often framed as a rupture with the vision of the Founding Fathers or the intention of the text of the U.S. Constitution (Fea, 2016). This is amplified, for example, by a focus on constitutional originalism among some Supreme Court justices and the expectation that it is through them that religious freedom must be defended.

In Europe, right-wing movements tend to employ the rhetoric of a Judaeo-Christian Europe, but the way in which they do so differs between national contexts. For example, those who operate in a more confessional space, like in Poland or Hungary, might instrumentalise Christian morality, for example with regards to gender and sexuality, in order to push back against "Western" liberalism. Concurrently, Hungarian nationalism emphasises identity through ethnicity, inclusive of ethnic Hungarians living in neighbouring states; it is no coincidence that the new constitution was named the "Fundamental Law" instead of "the constitution", and was understood to follow in the steps of the "ancient constitution" (Hörcher \& Lorman, 2019). This binds the concept of "constitutional identity" to the "Hungarian nation" (Trócsányi, 2016). Fidesz, Viktor Orban's party, has gone to great lengths to associate this Fundamental Law with the imaginary of the historically ethnic Christian nation, which always sought to shrug off imperial influences, be it from East or West. In other spaces, like Germany and France, where religious leadership came out strongly against the Alternative für Deutschland or the Rassemblement National, right-wing movements have been more cautious (Elcott et al., 2021: 54-55). Nations differ in how they institutionally relate church and state, and these divergent 
settlements seem to impact support for or opposition to populist movements (Cremer, 2021). In instances where the clergy opposed right-wing movements, references to Christianity tended to be limited to a cultural Christianity, often unapologetically so, and Christians in these movements tend to be marginalised. This is very different from the interwovenness of right-wing movements and religious elites in Poland and Hungary. It shows that Christian references may be employed purely secularly, as in the Dutch party Forum voor Democratie; that they might function primarily culturally, like in France or Germany; or may have some specific religious content, as in Hungary.

These examples demonstrate that whilst this secularised or culturalized Christianity might subsume more explicitly confessional claims, most fundamentally, these stories can often dispense with the confessional side of Christianity. In contexts where churches are relatively dominant, such as in the United States, in Poland or in Hungary, their history with Christianity can be politically convenient but right-wing movements do not define themselves by it, nor do they pretend so. What emerges is the idea of "the people" that is differentiated from the people. This subset of the true people is cast as sovereign and therefore, they can define for themselves what amounts to good and evil. To come back to the idea of an eschatological typology of time: this typology, in its secularised appearance, has the power to construct a story of good and evil that it projects onto the past, the present, and the future. Christian theology may provide certain typological structures, but it is like a skeleton, with varying amounts of flesh on the bone. Christian theology and belief appears to be largely irrelevant to this sacralisation of the people and this sacralisation of history. Nonetheless, it is primarily through the sacralisation of history that its secularised eschatological narrative is performed.

\section{Conclusion}

The significance of Christian theological and philosophical conceptions of time and "the people" to right-wing and far-right movements in Europe and North America cannot be underestimated. The secularisation of eschatology through a strong association of good and evil with "the people" and its imagined enemies helps us to understand the ambivalence of being at once dominant and threatened. Moreover, the explicit reliance on Christian images, narratives, and symbols contributes to a sacralisation of "the people" that takes on (secular) religious dimensions. This sacralisation of "the people" is made complete temporally through the sacralisation of history. Christian identity, however, serves as a largely cultural agent of belonging: most right-wing populist movements dispense with confessional dimensions to Christianity. Even in Hungary, where Christianity is wielded as a moral agent by Fidesz, Christianity is still not necessary because ethnicity and historical opposition to imperialism from East and West have strong resonances too. What follows, is that the instrumentalization of Christian typologies of time embodies secularisation, even as they appear to counter it, or can wear a cloak of piety. This nationalist rendition of "the people" thus becomes the epitome of the "secular sacred".

Typologies of time are of course not illegitimate as such, and they continue to shape much of the Latin-Christian imagination. However, it is their unchecked leverage for specific political purposes that this article and issue critiques: the differentiation of the people and "the people" undermines the political order, whether or not this order is seen as liberal, democratic, or constitutional. It allows first for abstract disidentification and othering, and it opens the door for concrete disidentification and the marginalisation of those dubbed as enemies of "the people" (Gülerce, 2014). It carries an allusion to the end times, or "the coming of the Son of Man", in which political ideology becomes the Judge: 'Then two will be in the field; one will be taken and one will be left. Two women will be grinding meal together; one will be taken and one will be left' (Matthew 24: 40-41). That is the consequence 
of secularised eschatology. The tracing of theological and philosophical dimensions to categories such as contemporary populism, nationalism, and the far-right is important for political science, not only in its Latin-Christian contexts. Non-Christian populism movements and parties may draw on a different set of imaginaries, as Turkmen describes in her work Under the Banner of Islam on religious nationalism in Turkey (Turkmen, 2021). The question is how religious communities relate to appropriations of religious typologies and imaginaries. Are they ready to share the ownership over these ideas? Are they willingly complicit in legitimising the vilification of "the people's" others? And how does it relate to religious hope?

\section{Bibliography}

Abaza, M. (2007). "The dialectics of enlightenment, barbarism and Islam" (Ortelius Lecture 5). Wassenaar: Netherlands Institute for Advanced Study in the Humanities and Social Sciences.

Arato, A. (2013). "Political Theology and Populism". Social Research: An International Quarterly, 80 (1): 143-172.

Barbero, I. (2012). "Orientalising citizenship: the legitimation of immigration regimes in the European z Union". Citizenship Studies, 16 (5-6): 751-768.

Beckmann, K. (2002). Die fremde Wurzel. Altes Testament und Judentum in der evangelischen Theologie des 19. Jahrhunderts. Göttingen: Vandenhoeck \& Ruprecht.

Boer, R. (2009). Political Myth: On the Use and Abuse of Biblical Themes. Durham: Duke University Press.

Bozóki, A. 2017. "Mainstreaming the Far Right: Cultural Politics in Hungary". Perspective Politice, 10 (1): 83-89.

Byrd, J. P. (2002). The Challenges of Roger Williams: Religious Liberty, Violent Persecution, and the Bible. Macon: Mercer University Press.

Cammaerts, B. (2018). "The Mainstreaming of Extreme Right-Wing Populism in the Low Countries: What is to be Done?”. Communication Culture \& Critique, 11: 7-20.

Carothers, T. (2019). "The Long Path of Polarization in the United States”. In: T. Carothers and A. O'Donahue (eds.) Democracies Divided: The Global Challenge of Polarization, Washington: The Brookings Institution.

Carter, J. K. (2008). Race: A Theological Account. Oxford: Oxford: Oxford University Press.

Chaplin, J. (2021). "A political theology of 'the people': Enlisting Classical Concepts for Contemporary Critique”. In: U. Schmiedel and J. Ralston (eds.) The Spirit of Populism. Leiden: Brill.

Cremer, T. (2021). "Nations under God: How Church-State Relationships Shape Responses to Right-Wing Populism in Germany and the United States". Religions, 12 (254): 1-21.

Davis, J. T. and Perry, S. L. (2020). "White Christian Nationalism and Relative Political Tolerance for Racists". Social Problems, 68 (3): 513-534.

Dreher, R. (2017). The Benedict Option: A Strategy for Christians in a Post-Christian Nation. New York: Penguin.

Eatwell, R. and Goodwin, M. (2018). National Populism: The Revolt Against Liberal Democracy. London: Penguin.

Elcott, D. M., Anderson, C. C., Cremer, T., and Haarmann, V. (2021). Faith, Nationalism, and the Future of Liberal Democracy. Notre Dame: University of Notre Dame Press.

Fabian, J. (1983). Time and the Other: How Anthropology Makes its Object. Repr; New York: Columbia University Press 2014.

Fea, J. (2016). Was America Founded as a Christian Nation? A Historical Introduction. Rev. ed.; Louisville: Westminster John Knox.

Gorski, P. S. (2017). American Covenant: A History of Civil Religion from the Puritans to the Present. Princeton: Princeton University Press.

Gorski, P. S. (2020). American Babylon: Christianity and Democracy Before and After Trump. London: Routledge.

Green, E. (2021). “A Christian Insurrection”. The Atlantic (8 January 2021).

Gülerce, A. (2014). "Selfing as, with and without othering: dialogical (im)possibilities with Dialogical Self Theory". Culture \& Psychology, 20 (2): 244-255.

Hart, R. P. (2020). Trump and Us: What He Says and Why People Listen. Cambridge: Cambridge University Press. Hauerwas, S. and Willimon, W. (1989). Resident Aliens: Life in the Christian Colony. Nashville: Abingdon Press.

Hayes, Z. (1987). Visions of a Future: A Study of Christian Eschatology. Wilmington: The Liturgical Press.

Hörcher, F. and Lorman, H. (2019). A History of the Hungarian Constitution. Law Government and Political Culture in Central Europe. London: Bloomsbury. 
Ilany, O. (2018). In Search of the Hebrew People: Bible and Nation in the German Enlightenment. Bloomington: Indiana University Press.

Jennings, W. J. (2010). The Christian Imagination: Theology and the Origins of Race. New Haven: Yale University Press.

Juergensmeyer, M. (2001). Terror in the Mind of God: The Global Rise of Religious Violence. Rev. ed.; Berkeley: University of California Press.

Koselleck, R. (1979). Vergangene Zukunft: Zur Semantik Geschichtlicher Zeiten, translated by K. Tribe, Futures Past: On the Semantics of Historical Time. New York: Columbia University Press 2004.

Lee, E. (2019). America for Americans: A History of Xenophobia in the United States. New York: Basic.

Marzouki, N., McDonnell, D. and Roy, O. (2016). Saving the People: How Populists Hijack Religion. London: Hurst \& Company.

McIvor, M. (2021). Representing God: Christian Legal Activism in Contemporary England. Princeton: Princeton University Press.

Moltmann, J. (2004). Das Kommen Gottes: Christliche Eschatologie, translated by Margaret Kohl, The Coming of God: Christian Eschatology. Minneapolis: Fortress Press.

Mudde, C. (2017). "Populism: an ideational approach". In: C. R. Kaltwasser et al. (eds.) The Oxford Handbook of Populism. Oxford: Oxford University Press.

Müller, J-W. (2016). What is Populism? Philadelphia: University of Pennsylvania Press.

Otieno, R. F., Owino, F.R. and Attyang, J. M. (2016). "Metaphors in Political Discourse: a review of selected studies". International Journal of English and Literature, 7 (2): 21-26.

Ozzano, L. and Bolzonar, F. (2020). "Is Right-Wing Populism a Phenomenon of Religious Dissent? The Cases of the Lega and the Rassemblement National”. International Journal of Religion 1 (1): 45-59.

Póczik, S. and Sárik, E. (2019). "Vigilante militias and activities against Roma and migrants in Hungary". In: T. Bjørgo and M. Mareš (eds.) Vigilantism against Minorities and Migrants. London: Routledge.

Rowley, M. P. (2017). “'All Pretend an Holy War:' Radical Beliefs and the Rejection of Persecution in the Mind of Roger Williams". Review of Faith \& International Affairs, 15 (2): 66-76.

Rowley, M. P. (2019). "Stop Weaponizing the Bible for Trump: No Politician Is a Cyrus, David or Caesar". Washington Post (19 June 2019).

Rowley, M. P. (2021). Trump and the Protestant Reaction to Make America Great Again. London: Routledge.

Smith, J. K. A. (2017). Awaiting the King: Reforming Public Theology. Grand Rapids: Baker.

Soper, J. C. and Fetzer, J. S. (2018). Religion and Nationalism in Global Perspective. Cambridge: Cambridge University Press.

Sterkenburg, N. (2021). Maar Dat Mag Je Niet Zeggen: De nieuwe generatie radiaal- en extreemrechts in Nederland. Amsterdam: Das Mag.

Stögner, K. (2020). "Intersectionality and Antisemitism - A New Approach". Fathom, https:/ / fathomjournal.org/intersectionality-and-antisemitism-a-new-approach/ (22 March 2021).

Strommen, H. (2021). "Sacred Scripts of Populism: Scripture-Practices in the European Far Right". In: U. Schmiedel and J. Ralston (eds.) The Spirit of Populism. Leiden: Brill 2021.

Strommen, H. and Schmiedel, U. (2020). The Claim to Christianity: Responding to the Far Right. London: SCM Press.

Suchocki, M. H. (2005). The End of Evil: Process Eschatology in Historical Context. Eugene: Wipf \& Stock.

Trócsányi, L. (2016). The Dilemmas of Drafting the Hungarian Fundamental Law. Constitutional identity and European integration. Passau: Schenk Verlag.

Turkmen, G. (2021). Under the Banner of Islam. Oxford: Oxford University Press.

Vachudova, M. A. (2019). "From Competition to Polarization in Central Europe: how populists change party systems and the European Union". Polity 51 (4): 689-706.

$V$ an de Breevaart, J. O. (2020). Concurrent of Bondgenoot: een christelijk perspectief op populisme. Apeldoorn: De Banier.

van der Tol, M. D. C. (2020). Politics of Religious Diversity: Toleration, Religious Freedom and Visibility of Religion in Public Space. PhD thesis, University of Cambridge.

van der Tol, M. D. C. (2021). "Politics of Belonging in the Nation State: Reclaiming Christianity from Populism". In: U. Schmiedel and J. Ralston (eds.) The Spirit of Populism. Leiden: Brill 2021.

Walsham, A. (2006). Charitable Hatred: Tolerance and Intolerance in England, 1500-1700. Manchester: Manchester University Press.

Westhelle, V. (2012). Eschatology and Space: The Lost Dimension in Theology Past and Present. New York: Palgrave Macmillan.

Whitehead, A. L. and Perry S. L. (2020). Taking America Back for God. Oxford: Oxford University Press. 